\section{Banks in Queer Street}

Western banks should tell their customers they have lost money on loans to poor countries.

FunNY things are happening in the West's commercial banks. For the past two months, many of the banks have been saying that their assets are worth less than previously thought. The curious consequence has been that those who invest on the world's stock-markets have judged the same banks to be worth more. This phenomenon deserves more attention than it has been given, because of its bearing on the relationship between the rich and the poor countries of the world.

The story begins in 1973, when petroleum-exporting countries (OPEC) increased the price of crude oil by a factor of three, which later grew to a factor of five, and began accumulating surpluses of more than $\$ 100,000$ million a year from the revenues they could not spend. The strange blend of inflation and slump in Western economies that followed is, in retrospect, easily explained. Dearer oil meant higher costs, but the transfer of resources to the oil producers meant that industrial states had less cash to invest in their own development. For a time it seemed as if the industrial countries would be in serious trouble, but it then emerged that the oil producers had no choice but to lend back their surpluses to the commercial banks. "Recycling" became the name of the bankers' game. Meanwhile, the poor countries, less attractive havens for oil producers' cash, were unable to pay for the oil they needed to stay afloat. Industrial governments, conscious of a moral pressure to help the less fortunate, then hit on what seemed a neat solution: persuade the commercial banks to recycle part of the oil producers' surpluses to the poor countries. Thus began the process by which the pauperization of the poor was made permanent. The debts of the developing countries, in round numbers a cool $\$ 500,000$ million, are growing as interest they cannot afford to pay is added to the principal sums outstanding.

Some exceptions to this general pattern stand out. Among industrial oil-consumers, West Germany and Japan always manfully paid for their oil at its higher price. Britain, apparently exempted from physical dependence on the oil producers by North Sea oil, was nevertheless compelled to pay the higher prices, without which much of the oil production of the past decade would not have been economic. Among the poor countries, India seems to have emerged most successfully, largely because of a green revolution and an increase in its industrial production. But once-proud poor oil-producers such as Mexico, Nigeria and Venezuela, having borrowed recycled money in the hope of sustaining general development are now saddled with debts they cannot pay.

For five years, most governments have been hoping that this mess would go away. Now the commercial banks have begun to acknowledge that it will not. West German and Swiss banks have been for five years prudently providing for the chance that some of their loans would never be repaid, but the big break came in May, when Citicorp, the largest US bank company, set aside $\$ 3,000$ million as an earnest of its diminished expectations. Other US banks followed suit, as have two in Britain. The most startling development so far is the decision of the British Midland Bank to sell off a fifth of its banking business in Britain and to drum up from its existing shareholders an extra $£ 700$ million, so as to set aside an extra $£ 915$ million in respect of overseas loans unlikely to be requited. The bank's shareholders have been told that it will cost them an extra $£ 700$ million to own a safe and profitable bank four-fifths the size of the business they believed they owned. That the shares of these banks have almost always increased in value is said to be a measure of the general welcome for their realism.

The consequences of these developments will be serious. Having had their fingers burned, the banks may now be tougher on future applications for loans to poor countries, which could be especially serious when almost all the governments of Latin America are queuing up in New York to renegotiate their present debts. Can it make sense that these negotiations should be left to the commercial banks, with a vested interest in making what they can of the assets whose value has been written off? It would be better that the banks writing off these assets (with the help of their governments' willingness not to tax the sums set aside to cover bad debts, which would otherwise have been profits) should be compelled to sell them at knockdown prices to, say, the International Monetary Fund, which could then negotiate with the debtor countries an equitable liquidation of the loans. But this is merely a crude solution of the problem. The governments and banks that created the imbalances in the first place should now recognize that the responsibility for finding a lasting solution rests with them.

\section{How to feed worlds}

\section{The United States advocates rationality in agri-} culture, not before time.

THE Reagan administration in the United States, which has not enjoyed much adulation in recent months, deserves high marks for what it had to say about agriculture at Geneva ten days ago. Briefly, US trade representatives helping to plan the intended renegotiation of the General Agreement on Tariffs and Trade (GATT) said that one of their objectives was the abolition of all agricultural subsidies by all governments within a decade. The farmers in the Middle West baulk at the news, but elsewhere there should be an unstinted welcome for this notion.

Why should agricultural subsidies matter so much that mere talk of their removal is good news? Everybody knows that, at least in industrial countries, governments subsidize agriculture. In the old days, when many countries were forced to be selfsufficient economic units, there were respectable excuses. Given climatic fluctuations, it made sense to sustain production at levels that would be sufficient even in bad years. It is also proper that governments should pay some attention to the welfare of farming communities. The costs of these policies appear in one of two ways. Either people must pay higher taxes so that farmers can be subsidized, which is the pattern in the United States, or food prices are manipulated so that food-consumers pay farmers directly, which is the European practice.

The immediate losers are the consumers, who pay more for food than would otherwise be necessary. In most places, consumers do not complain too loudly; farm subsidies tend to be a small fraction of gross national product and country-folk are likeable people. But consumers do from time to time protest; even well-to-do Japan is occasionally up in arms at the high price of rice, sustained at several times the world market price by a system of guaranteed farmers' prices (just reduced by 6 per cent) and import controls. But the big money is spent in Europe and the United States (roughly $\$ 30,000$ million a year cash), some of it during the past year in underbidding for the markets for grain in places such as Egypt. What seems now to have happened is that the United States has realized that further intensified competition along these lines is a recipe for bankruptcy. Europe, wedded to the ideology of its Common Agricultural Policy, cannot see the danger.

The more real present losers in this competition are not the principal actors but those who stand on the sidelines - some major food producers (Canada, Argentina, Australia and New Zealand) and many potential food-producers, several of the developing countries in which food production would increase at least to the point of self-sufficiency if the markets were not rigged against them. More generally, agricultural subsidies are a device for making sure that people everywhere work at tasks that suit them less than well. If the United States can make the lesson stick - and make the US Congress listen - it will have done a great public service. 